
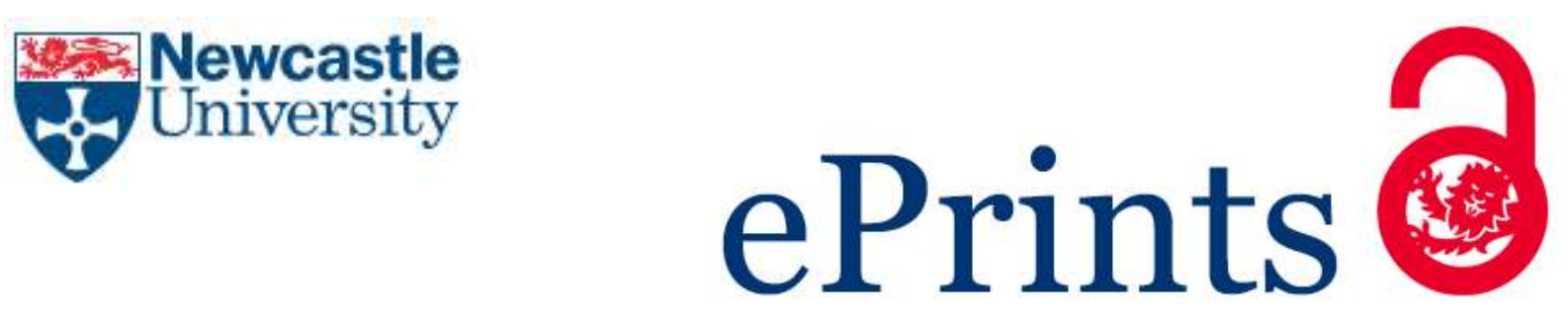

Futoransky L, Page P. De Cartografías sentimentales/Affective cartographies de Luisa Futoransky. Confluencia: Revista Hispánica de Cultura y Literatura 2016. Department of Hispanic Studies, University of Northern Colorado, USA, 31(2), 233-243.

Copyright:

This is the open access version of an article that has been published by Department of Hispanic Studies, University of Northern Colorado, 2016

DOI link to article:

http://dx.doi.org/10.1353/cnf.2016.0001

Date deposited:

$28 / 02 / 2017$

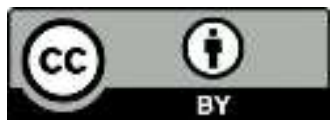

This work is licensed under a Creative Commons Attribution 4.0 International License 


\title{
De Cartografías sentimentales/Affective cartographies de Luisa Futoransky ${ }^{1}$
}

\author{
Philippa Page, translator
}

Argentine poet, Luisa Futoransky, has a long-standing fascination with the urban in her poetry. The following poems are a taster of her forthcoming bilingual anthology, Cartografias sentimentales/Affective cartographies, which brings together her poems about cities. The poems composing this new anthology together create an affective map that spans both decades and continents, each city ultimately co-existing in this mnemonic and sentimental cartography in the present. Some of the poems in this sample are the fruit of a fleeting encounter with the cities in question. Others lay bare a much more intimate relationship to the surroundings: namely Paris, Luisa Futoransky's current home, and Buenos Aires, the poet's home city, which often bears an unspoken -almost spectralpresence in her work. Here, she unmasks the urban and takes us into the viscera of cities that take on a personality of their own. 


\section{Insomnia on the rue de Charenton}

familiar sounds tendered by anonymous inhabitants

the newsboy at 3:35

the milkman at $4: 15$

the baker at 5:40

the neighbor relieving herself

a lover departing

rag-pickers rummaging through the trashcans

ob! Paris la nuit

\section{Insomnio en la Rue de Charenton}

los ruidos amigos que me tienden habitantes desconocidos

el repartidor de diarios a las 3,35

el repartidor de lácteos a las 4,15

el repartidor de pan a las 5,40

la vecina que orina

el amante que parte

los cirujas que revisan los tachos de basura

ob! paris la nuit 


\section{South bank selfie}

After many years living in the back yard

of cities that scintillate

let me begin

by telling you about one:

my city is not foundationally evasive but became that way over time;

dodging reality out of some sort of defensive bad habit,

ready to avoid she dribbles as if with a football,

she lies in truco, ${ }^{2}$ lies for all she's worth

until even she believes herself

she rewrites history

and repatriates remains

all that is left to entertain herself

for this and other great weaknesses my city

dresses up in a cape of pure paradox

invisible to those outside

what I mean is she believes hook line and sinker in one thing and its opposite

sometimes my city is diagnosed with schizophrenia

and autism to an extreme degree

add to this a foolproof sense of pride

and a cocky disdain

and the veristic portrait hardly bears temptation

in short a city of little check

and a lot of mate

and I who know not how to swim

flail

I flail to keep my head above water

but what of my feet 


\section{Selfie Costanera Sur}

Tras largo vivir en el patio trasero

de ciudades rutilantes

empiezo

contando una:

mi ciudad no es fundacionalmente huidiza pero se fue haciendo así;

por una suerte de vicio defensivo esquiva la realidad, puesta a esquivar gambetea como en el fútbol,

miente en el truco miente a más no poder

hasta que ella misma se la cree

modifica la historia

y no le queda otra que entretenerse

repatriando restos,

mi ciudad por estas y otras grandes debilidades

viste una capa de pura paradoja

invisible para los de afuera

es decir cree a pie juntillas en una cosa y su contrario

a veces diagnostican a mi ciudad esquizofrenia

y autismo en severas proporciones

si a eso le sumás soberbia y un menosprecio

el cuadro verista es poco tentador

ciudad en suma, de poco jaque

y mucho mate

y yo que sin saber nadar

manoteo

manoteo por sacar la cabeza fuera del agua

y los pies qué 


\section{Luminaries}

to Jason Weiss

instead of christmas lights

the menorahs of brighton show off with airs and graces

banks and convenience stores along the main avenue

a mottled steppe

of poor taste

markets and smoked fish stalls, stores offering leather, vegetables

caviar and manicures.

advertisements for sword swallowers, mermaids

human pyramids of coney island

rollercoaster, or russian mountain rather,

and other summer daredevilry

hunched over plastic laminate clusters of mafiosos

reminiscence is a step enclosed within the step itself

arteries gasping their last in the neva

the only river in mother russia i can recall

the cruel world is a frosted replica

whiffs of white liquor

so pure they clear mortal vermin

how much remains

hardly a simile of this shattered heart

honey, oy vey! honey

what's with the whimper 


\section{Luminarias}

a Jason Weiss

en vez de las iluminaciones navideñas

las menorahs de brighton, compadrean

en la gran avenida, los bancos y tugurios

un malgusto estepario

abigarrado

mercaditos y puestos de pescado ahumado, negocios de pieles

verduras, caviar y manicura.

anuncios de tragasables, sirenas

pirámides humanas de coney island

montaña rusa, como debe ser

y otros peligrosos atrevimientos veraniegos

por encima de la fórmica y los racimos de mafiosos

la reminiscencia es un paso enquistado dentro del propio paso

arterias que quedaron boqueando en el neva

único río que recuerdo de la patria rusa

el duromundo es una réplica empañada por la escarcha

las vaharadas de licor tan blanco

tan puro desbrozan de alimańas mortales

cuanto queda

apenas un símil del quebrantado corazón

nena, oy vei! nena

este gemido qué 


\section{With the Fingers}

what can be expected of an old man? That he books an appointment with specialists merely for them to confirm his irremediable deterioration as if he really needed to be told that he's killing time wandering and rest that his desires like him are retiring without joy from a life of his loved ones, the city, take revenge for his dirty old tricks and petulance

stairs multiply in front of him

soapy pavements

with nothing more than the swiftest of blows a hammering of the wind breaks his dentures

in the sink in the hotel and just to finish them off the night elves hurl them out of the window and the neighbourhood complains about the sudden hullabaloo dam these old codgers some say they smell as bad as tramps or prison walls because the smell of a class of adolescents in summertime turns one's stomach but in a different way

the old man lives in a vast country of people congested by repentance and conditional times a country of Peter Pan of filthy, dethroned little princes that the stinginess with which they open their cheque books does not air country of excrescences, tremors, coughs carpeted with nightmares upon my return to the academy I, Lazarus, impart as tradition obliges precious crusts, edicts of affection

the rainbow can be eaten with one's fingers the dew abates bad breath carrying precious stones in his pockets hinders flight letting go of them in the sky alleviates him deciphering alphabets in the shapes of the clouds dusts off the privation 
skating on thin ice

until it finally shatters

into a bright explosion of particles

for what other reason are things

people

socks

houses

elephants

made

but to be broken

just like that

all of a sudden

and knowingly 


\section{Con los dedos}

qué se espera de un viejo? que pida turno con especialistas

que le confirmarán por si falta le hacía el deterioro irremediable

que mate el tiempo que sus deseos como él se jubilen sin júbilo de la vida del paso y el [respiro

sus allegados, la ciudad, se vengan de sus antiguas perrerías y petulancia

le multiplican escaleras

veredas jabonosas

apenas con un alfiler

un martillito de viento le quiebran la dentadura postiza

en el lavabo del hotel

y para rematarla los duendes de la noche la tiran por la ventana

y el vecindario se queja por ruidos molestos

intempestivos

joder con los viejos

hay quien dice que huelen tan mal como los linyeras

o los muros de las prisiones

porque el olor de una clase de adolescentes en verano

voltea marea

distinto

el viejo vive en un inmenso país de gente resfriada

por el arrepentimiento y los tiempos condicionales

un país de peter pan

de principitos destronados y cochambrosos

que la parsimonia con que abren sus chequeras no ventila

país de excrecencias, temblores, toses

alfombrado de pesadillas

yo lázaro transmito

al volver de la academia

tradición obliga

preciosos mendrugos, edictos de cariño

el arcoiris se come con los dedos

el rocío aminora el mal aliento

las piedras preciosas en los bolsillos dificultan el vuelo

soltarlas en el firmamento lo aligeran 
descifrar alfabetos en la forma de las nubes desempolva la penuria tirar del cántaro

hasta que por fin se rompa

en una luminosa astilladura de partículas

para qué otra cosa están hechos acaso los cántaros

la gente

las medias

las casas

los elefantes

sino para romperse

así

de repente

y a sabiendas 


\section{Paris, the imposture}

stingy, negligent, costive

coveted

the most effortlessly graceful

looking down her nose, magnificent at a distance

paris the concealer

cloistered in her own delusion of grandeur

cantankerous

paris buried in catacombs, paris for the initiated

paris empress and guillotine

i, who never overcame your myriad ramparts, snares, labyrinths

so effective in befuddling the foreigner,

know not whether i really loved, or indeed still love, you

\section{París, la impostura}

Tacaña, negligente, estreñida,

envidiada,

la más grácil sin esfuerzo,

ninguneadora, bella de lejos,

parís encubridora

recluida en su propio delirio de grandeza

atrabiliaria

parís oculta en catacumbas parís para iniciados

parís emperatriz y guillotina

yo, que nunca salvé tus innúmeras murallas, trampas, laberintos tan eficaces para perder al extranjero

no sé si te quise o quiero, todavía.

\section{Notas}

${ }^{1}$ Luisa Futoransky is an Argentine writer and journalist. She has published extensively across a range of genres, but is most renowned for her poetry. Her work spans over five decades, the most recent collections being Ortigas (Leviatán, 2011) and Pintura rupestre (Leviatán, 2014). Among her many awards, she was named a Chevalier in the French Ordre des arts et lettres in 1990. In April 2015, she was given the prize at the Festival Internacional de Poesía in Buenos Aires. Her work has been translated into French, English, Italian, Hebrew, Portuguese, Japanese and German.

Philippa Page is Assistant Professor in Spanish and Film at Newcastle University in U.K, where she lectures on contemporary Latin American culture, international film and translation studies. Her research focuses on contemporary literature and film in the Southern Cone.

${ }^{2}$ Truco is a typically Argentine card game, which strategically relies very much on being able to dupe opponents as to the worth of the cards in hand. 